\title{
O CAPITAL PORTADOR DE JUROS EM O CAPITAL OU O SISTEMA DE MARX ${ }^{1}$
}

\author{
Leonardo André Paes Müller ${ }^{2}$ \\ Leda Maria Paulani ${ }^{3}$
}

RESUMO: O presente artigo busca estabelecer o local e a função do capital portador de juros em $O$ Capital, visando com isso jogar luz sobre a estrutura eminentemente sistemática desta obra. Deste modo a obra máxima de Marx aparecerá muito próxima do idealismo alemão (particularmente de Fichte e Hegel), onde a questấo da sistematicidade (da filosofia) foi sentida de maneira mais premente.

PALAVRAS-CHAVE: Sistema. Círculo. Negação. Valor. Capital. Juros.

\section{A Completude ou o círculo do capital}

Em sua Doutrina da ciência (Wissenschaftslehre) de 1794, Fichte nos apresenta o problema da completude (Vollständigkeit). ${ }^{4}$ Essa doutrina só

\footnotetext{
${ }^{1}$ Este texto foi desenvolvido no âmbito das atividades do CAFIN, grupo de pesquisa em Instituiçốes do Capitalismo Financeiro (com registro no $\mathrm{CNPq}$ ) e é resultado dos desdobramentos da atividade de orientação de Iniciaçáo Científica do primeiro autor pela segunda autora. Ele é, nesse sentido, parte da pesquisa Dominância da Valorização Financeira e Padrão Dólar-Dólar, de autoria da segunda autora e financiada pelo $\mathrm{CNPq}$ (Bolsa de Produtividade em Pesquisa), investigação, que, em sua primeira parte, busca justamente retomar as discussóes em torno dos fundamentos e do lugar do dinheiro e do capital portador de juros, em O Capital, de Karl Marx.

${ }^{2}$ Economista pela FEA-USP, Mestre em Filosofia pela FFLCH-USP e Doutorando em Filosofia na FFLCH-USP. E-mail: lapmuller@gmail.com.

${ }^{3}$ Professora Titular do Departamento de Economia da FEA-USP e do Curso de Pós-Graduação em Economia do IPE-USP. Bolsista de Produtividade do CNPq.

${ }^{4}$ Questão que pode ser remontada a Kant e “[...] por si só, resume toda a problemática da filosofia clássica alemâ" (ARANTES, 2000, p. 360). Sobre essa questão em Kant, ver LEBRUN, 1971 (especialmente o capítulo 7). Sobre a relação dessa questão em geral e da Wissenschaftslehre, em particular, com o sistema hegeliano, ver HÖSLE, 2007 (especialmente o capítulo 2).
} 
corresponderá a seu conceito se esgotar em sua totalidade o saber humano em geral, o que só é possível se seu princípio for esgotado. $\mathrm{O}$ esgotamento de um princípio significa que "[...] a derivação que ele institui dá lugar a um sistema completo: não há proposição verdadeira (ou sacada anteriormente do patrimônio total do saber humano) que não possa ser deduzida no interior do sistema" (ARANTES, 2000, p. 361), o que nos indica que podemos tomar "[...] o acabamento (Vollendung) da doutrina da ciência como prova positiva de que o sistema está concluso; todas as proposiçóes foram deduzidas no momento em que o princípio de que se partiu reaparece como o resultado último da derivação" (ARANTES, p. 361-362).

A seguinte passagem sintetiza o acima exposto: “Um princípio está esgotado quando foi construído sobre um sistema completo, isto é, se o princípio conduz necessariamente a todas as proposiçóes estabelecidas, e todas as proposiçóes estabelecidas reconduzem necessariamente a ele" (FICHTE, 1973, p. 26). ${ }^{5}$ O relevante aqui é ressaltar que

[a] dialética especulativa fará seu esse projeto de completude do sistema do saber e reportará a circularidade da derivação científica à identificação da progressão da determinação e da fundação retroativa do começo: a ciência será um circuito fechado criando-se e dando-se por si mesma seu objeto ou não será. (ARANTES, 2000, p. 362).

A hipótese deste artigo, que começa a ser desenvolvida nesta seção, consiste em afirmar que também em $O$ Capital encontramos articulada a completude.

Na primeira seção do Livro I, Marx nos apresenta a gênese do dinheiro a partir da mercadoria. Basta lembrar aqui a dialética da forma valor em suas três/quatro figuras: a Forma Simples, Singular ou Acidental de Valor (forma I), a Forma de Valor Total ou Desdobrada (forma II), a Forma Geral de Valor (forma III) e, por último, a Forma Dinheiro (forma IV). Sobre a passagem da forma III à forma IV, diz Marx:

\footnotetext{
${ }^{5} \mathrm{O}$ encadeamento das proposiçóes é a "prova negativa” do esgotamento de um princípio, encadeamento que leva à prova positiva: "A ciência é um sistema, ou está perfeita, quando nenhuma proposição mais pode ser inferida: e isto dá a prova positiva de que não foi acolhida no sistema nenhuma proposiçáo a menos". Por sua vez, o "[...] índice positivo para provar que, pura e simplesmente, incondicionalmente, nada mais pode ser inferido [...] não poderia ser outro do que verificar que o próprio princípio de que havíamos partido é também o último resultado. Então ficaria claro que não poderíamos ir adiante sem percorrer de novo o caminho já percorrido uma vez" (FICHTE, 1973, p. 26).
} 
A forma IV não difere em nada da forma III, a não ser que agora, em vez do linho, possui o ouro a forma de equivalente geral. [...] O progresso apenas consiste em que a forma de permutabilidade direta geral ou forma equivalente geral se fundiu agora definitivamente, por meio do hábito social, com a forma natural especifica da mercadoria ouro. (1983, p. 69, grifo nosso). ${ }^{6}$

Na seçáo II do mesmo Livro, temos a transformação do dinheiro em capital. Tendo mostrado que a circulação simples de mercadorias caracterizase pelo ciclo M-D-M, afirma Marx:

Ao lado dessa forma, encontramos, no entanto, uma segunda, especificamente diferenciada, a forma D-M-D, transformação de dinheiro em mercadoria e retransformação de mercadoria em dinheiro, comprar para vender. Dinheiro que em seu movimento descreve essa última circulação transforma-se em capital, torna-se capital e, de acordo com sua determinação, já é capital. (MARX, p. 125-126, grifo nosso).

O movimento percorrido aqui é, portanto: mercadoria $\rightarrow$ dinheiro $\rightarrow$ capital, o qual configura o caminho sintético de apresentação do capital.

No Livro III de O Capital, Marx focaliza o processo global da produção capitalista, que só pode ser levado a cabo através da individualização do capital global em capitais que atuam em esferas particulares da produção. Esse processo consiste na autonomização de alguns dos momentos desse movimento de (re)produção em atividades específicas que ficam a cargo de capitais individuais. Esta é a base da separação entre as esferas da produção e da circulação: a primeira fica a cargo do capital industrial, a segunda a cargo do capital comercial. O capital industrial é a base do modo de produção capitalista. É ali que se dá a relação fundamental entre capital e trabalho no processo produtivo, por meio da subordinação (formal e material) do último ao primeiro, e é gerada a mais-valia que permite ao capital ser esse movimento valorização do valor.

[Já o] capital comercial ou de comércio se divide em duas formas ou subespécies, o capital de comércio de mercadorias e capital de comércio de dinheiro [...] O capital global sempre se encontra empenhado no movimento dessa passagem, dessa metamorfose formal. À medida que essa

\footnotetext{
${ }^{6}$ As citaçôes de $O$ Capital são referentes aos cinco volumes da edição da coleção Os Economistas, publicada pela Abril Cultural. Consultamos também os volumes 21 a 25 da Werke de Marx e Engels, para o texto em alemão.
} 
função do capital, que se encontra no processo de circulação, passa a ser autonomizada como função específica de um capital específico, fixandose como uma função adjudicada pela divisão do trabalho, a uma espécie particular de capitalistas, o capital-mercadoria torna-se capital de comércio de mercadorias ou capital comercial. (1984c, p. 203).

Antes de mais, é preciso observar que, por não produzir valor - exceção feita ao serviço do transporte que nele pode estar incluso (MARX, 1984b, p. 42-43; MARX, 1984c, p. 108-110) - o capital comercial atua apenas no sentido de diminuir o tempo de circulação das mercadorias, isto é, atua no sentido de diminuir a um mínimo possível os custos de circulaçáo, os faux frais da produção capitalista (MARX, 1984c, p. 211-212). No entanto, esse capital "[...] apenas funcionando dentro da esfera da circulação" (MARX, 1984c, p. 211) duplica-se, por sua vez em "[...] capital de comércio de mercadorias" e em “[...] capital de comércio de dinheiro” (MARX, 1984c, p. 221-222). No primeiro, encontram-se todos os capitais relacionados à circulação das mercadorias: transportes, estocagem, comércio (atacadista e varejista) etc.

Contudo, o que devemos compreender por comércio de dinheiro? Ora, um comércio cuja mercadoria seja o próprio dinheiro. Mas como isso é possível? "Do capital global se separa agora e se autonomiza determinada parte em forma de capital monetário, cuja função capitalista consiste exclusivamente em executar para toda a classe dos capitalistas industriais e comerciais essas operaçóes", isto é, "[...] os movimentos puramente técnicos que o dinheiro realiza no processo de circulação do capital industrial” (MARX, 1984c, p. 237). ${ }^{7}$

Não se trata aqui de uma nova determinação do capital, mas sim do resultado do movimento do capital, qual seja, a plena posição do dinheiro (MARX, 1984c, p. 238). Nesse comércio de dinheiro, entram também a moeda nacional e a moeda internacional, porém, a mercadoria que realmente nos interessa é a desenvolvida na seção V do Livro III: a "mercadoria-capital" (MARX, 1984c, p. 255).

\footnotetext{
7 Um pouco mais adiante, na discussão sobre crédito e capital fictício, Marx observa que, a esse comércio de dinheiro, para além da execuçâo dos movimentos puramente técnicos que o dinheiro realiza no processo de circulação, liga-se também um dos aspectos do sistema de crédito, qual seja, "[...] a administraçáo do capital portador de juros ou do capital monetário, como funçáo particular dos comerciantes de dinheiro. [...] [Os banqueiros] tornam-se os administradores gerais do capital monetário" (1984c, p. 303). O outro aspecto do sistema de crédito antes tratado por Marx refere-se ao crédito que os capitalistas se concedem entre si, em determinada cadeia produtiva, e cujos papéis constituem a base do dinheiro de crédito.
} 
A apresentação dessa mercadoria será feita na próxima seção. Por ora, cabe retomar o movimento descrito até aqui. Se, no Livro I, o movimento foi da mercadoria ao capital, aqui o movimento é inverso: vai-se do capital global para a mercadoria, através do dinheiro. É na figura do dinheiro (de empréstimo) que o capital se transforma em mercadoria. $\mathrm{O}$ movimento aqui é, portanto: capital $\rightarrow$ dinheiro $\rightarrow$ mercadoria. Ao contrário do movimento anterior, sintético, este é analítico, porque resultado da decomposição do capital global em suas partes (indústria e comércio, comércio de mercadorias e de dinheiro, dinheiro internacional e nacional, mera compensação financeira de transações mercantis e dinheiro de empréstimo). ${ }^{8}$ Eis que a linha se curvou sobre si mesma, e o círculo foi fechado (cf. HEGEL, 1986a, p. 164).

\section{O PREÇO OU O JUÍZO INFINITO DA MERCADORIA 9}

Invertendo a lógica iluminista tradicional, na qual a aparência metafísica e teológica da realidade esconde um fundamento simples, ordinário, Marx salienta: "À primeira vista a mercadoria parece uma coisa trivial, evidente. Analisando-a, vê-se que ela é uma coisa muito complicada, cheia de sutileza metafísica e manhas teológicas" (MARX, 1983, p. 70).

Mais à frente, ele se pergunta: "De onde provém o caráter enigmático do produto do trabalho, tão logo ele assume a forma mercadoria?", para responder: "Evidentemente, dessa forma mesmo" (MARX, 1983, p. 71). Eis o fetichismo da mercadoria, que deriva "[...] do caráter social peculiar do trabalho que produz mercadoria” (MARX, 1983, p. 71).

\footnotetext{
8 "É desse modo que cada passo da progressão na determinação ulterior, na medida em que se afasta do início indeterminado, é também uma aproximação regressiva do mesmo, de tal modo que o que inicialmente pode parecer ser distinto, o fundamentar regressivo do início e o determinar ulterior progressivo do mesmo, recaem um no outro e são o mesmo. $\mathrm{O}$ método que com isso se fecha em um círculo não pode, porém, antecipar em um desenvolvimento temporal o fato de que o início já é como tal algo deduzido; para o início em sua imediatidade é suficiente que ele é universalidade simples" (HEGEL, 1986b, p. 570, grifo do autor).

9 Quem desenvolveu a "teoria dos juízos" de O Capital foi Ruy Fausto. Nela, constam: a) o juízo de reflexão: que indica a passagem do sujeito no predicado ("o homem é operário", "o homem é capitalista", cf. 1983, p. 27-37), característico de juízos onde o sujeito ainda não está plenamente constituído (ele é e não é); b) o juízo de sujeito: que apresenta o movimento ("o capital é mercadoria", "o capital é dinheiro", cf. 1983, ibidem), característico de sujeitos já constituídos, já postos; e c) juízo de inerência: que indica a adequação da matéria à forma ("o dinheiro é ouro", cf. 1983, p. 169-170 e "o capital é sistema mecânico", cf. 2003, p. 123-124). Estamos acrescentando mais um juízo a este rol: o juízo infinito.
} 
Todavia, cabe aqui a pergunta: toda mercadoria é produto do trabalho? $\mathrm{Ou}$, inversamente, há mercadorias que não são produtos do trabalho? A resposta a esta última questão é positiva:

Coisas que em si e para si não são mercadorias, como, por exemplo, consciência, honra, etc., podem ser postas à venda por dinheiro pelos seus possuidores e assim receber, por meio de seu preço, a forma mercadoria. Por isso uma coisa pode, formalmente, ter um preço, sem ter um valor. (MARX, 1983, p. 92, grifo nosso). ${ }^{10}$

Vemos, pois, que cabe ao preço operar um verdadeiro "milagre": ele garante não somente a "[...] possibilidade da incongruência quantitativa entre preço e grandeza de valor [...] [possibilidade esta que é] inerente à própria forma preço" ${ }^{11}$, como também "[...] a forma preço [...] pode encerrar uma contradição qualitativa, de modo que o preço deixa de todo de ser a expressão de valor" (MARX, 1983, p. 92), tal qual nos exemplos acima. ${ }^{12}$

$\mathrm{Na}$ Fenomenologia do Espirito, Hegel apresenta o juízo infinito do espírito: “[...] o ser do espírito é um osso" (2002, \$343), e insiste que há dois modos de lê-lo. Um próprio a alguém "[...] que não possui consciência do que diz” (2002, \$345) e outro, que surge do primeiro, e é propriamente especulativo. O primeiro modo consiste em maquiar "[...] esse pensamento com a mesma carência de pensamento, misturando relaçóes variadas de causa e efeito, de signo, de órgão, etc., que aqui não tem nenhum sentido dissimulando dessa maneira, por diferenças que delas derivam o chocante dessa proposição" (HEGEL, 2002, $\$ 345$ ). Já a compreensão especulativa consiste em afirmar esse juízo em seu contrassenso: "[...] ele deve (soll) ser um juízo, por conseguinte, conter uma relação (Beziehung) entre sujeito e predicado; mas tal relação, ao mesmo tempo, não pode (soll) ser" (HEGEL, 1986b, p. 324). De fato, esse juízo exprime “[...] a conexão do sublime e do ínfimo,

\footnotetext{
${ }^{10} \mathrm{O}$ preço nada mais é que o valor de troca expresso no valor de uso da mercadoria que ocupa o lugar de dinheiro: "A expressão relativa simples de valor de uma mercadoria [...] na mercadoria que funciona como mercadoria dinheiro [...] é a forma preço" (MARX, 1983, p. 69). Ele nada mais é que "[...] a denominação monetária do trabalho objetivado na mercadoria" (idem, p. 92). Mais à frente, veremos as consequências desse "ser nada mais que".

${ }^{11} \mathrm{O}$ que a torna "[...] a forma adequada a um modo de produção em que a regra somente pode imporse como lei cega da média à falta de qualquer outra regra” (MARX, 1983, p. 92).

12 Cabe lembrar que também a terra tem um preço, sem ter um valor (já que não é produzida pelo trabalho humano). Segundo Marx, seu preço expressaria o montante monetário resultante da capitalização, à taxa de juros vigente, dos rendimentos futuros que sua propriedade permite esperar.
} 
que no organismo vivo a natureza exprime ingenuamente, na combinação do órgão de sua maior perfeição - o da geração - com o aparelho urinário" (2002, \$346).

Analogamente, se digo que "a mercadoria é produto do trabalho", não esgoto o sujeito, pois, coisas que não são produtos do trabalho também podem ser mercadoria. Já os juízos "a mercadoria é consciência” ou "a mercadoria é honra" expressam o outro lado desse osso que é o ser da mercadoria, o lado do baralhamento, da confusão, da promiscuidade. Em poucas palavras, através do preço, coisas que não são, em si e para si, mercadorias transformam-se em mercadorias. É o que ocorre com o capital. ${ }^{13}$

\section{O EMPRÉSTIMO OU A MERCADORIA CAPITAL}

Dinheiro - considerado aqui como expressão autônoma de uma soma de valor [...] - pode na base da produçáo capitalista, ser transformado em capital e, em virtude dessa transformaçáo, passar de um valor dado para um valor que se valoriza a si mesmo, que se multiplica. Produz lucro, isto é, capacita o capitalista a extrair dos trabalhadores determinado quantum de trabalho não pago, mais produto, mais valia, e apropriar-se dele. Assim adquire, além do valor de uso que possui como dinheiro, um valor de uso adicional, a saber, o de funcionar como capital. Seu valor de uso consiste aqui justamente no lucro que, uma vez transformado em capital, produz. Nessa qualidade de capital possível, de meio para a produçáo de lucro, torna-se mercadoria, mas uma mercadoria sui generis. Ou, o que dá no mesmo, o capital enquanto capital se torna mercadoria. (MARX, 1984c, p. 255, grifo nosso).

À primeira vista, essa mercadoria, como qualquer outra, não apresenta grandes dificuldades: "A parte do lucro que lhe paga [isto é, que o mutuário paga ao prestamista] se chama juro, e que, portanto, nada mais é que um nome particular, uma rubrica particular para uma parte do lucro, a qual o capital em funcionamento, em vez de pôr no próprio bolso, tem de pagar ao proprietário do capital" (MARX, 1984c, p. 256, grifo nosso). No entanto, sabemos que

13 De maneira geral, podemos compreender o advento do modo de produção capitalista como um processo de mercantilização crescente da vida social. A questão é que há alguns "bens" que, ao serem mercantilizados, operam uma reviravolta na apresentação categorial: o primeiro é a força de trabalho, que opera a posiçáo do capital e traz consigo a categoria salário; o segundo é o próprio capital, de cujas consequências trataremos a seguir (e traz consigo duas categorias, lucro e juro); já o terceiro, mencionado na nota anterior, mas que não será objeto de estudo neste artigo, é a terra, cuja mercantilização está intimamente relacionada à da força de trabalho (cercamentos) e que traz consigo a categoria renda. 
as coisas não são tão simples: analisando a mercadoria capital, "[...] vê-se que ela é uma coisa muito complicada, cheia de sutileza metafísica e manhas teológicas”. Partamos da circulação desta mercadoria: D - D - M - D' - D'.

O empréstimo (movimentos D - D e D' - D') duplica o dispêndio do dinheiro como capital ( $\mathrm{D}-\mathrm{M}-\mathrm{D}$ '), duplicando também o seu retorno: 1) lucro ao capitalista e 2) juros ao prestamista. Aos olhos do prestamista, entretanto, "[...] a mediação desapareceu" (MARX, 1984c, p. 258) devido à "[...] natureza peculiar" da mercadoria capital e de seu ciclo próprio (D - D') (MARX, 1984c, p. 262).

O movimento característico do capital em geral, o retorno do dinheiro ao capitalista, o retorno do capital a seu ponto de partida, recebe no capital portador de juros uma figura totalmente externa, separada do movimento real de que é a forma. [...] O movimento real do dinheiro emprestado como capital é uma operação situada além das transaçôes entre prestamistas e mutuários. Nestas, essa mediação é apagada, invisível, não está diretamente implícita. [...] no caso do capital portador de juros, o retorno bem como a entrega são apenas resultados de uma transaçáo jurídica entre o proprietário do capital e uma segunda pessoa. Vemos somente entrega e reembolso. Tudo que ocorre de permeio é apagado. (MARX, 1984c, p. 262-263, grifo nosso).

Antes de observarmos mais de perto esse movimento de duplicação - a exteriorização do capital de si mesmo - analisemos o juro.

\section{O JURO OU A NEGAÇÃo DA NEGAÇÁo DO VALOR}

$\mathrm{Na}$ circulação simples de mercadorias, $\mathrm{M}-\mathrm{D}-\mathrm{M}$, temos a transformação da mercadoria em dinheiro e a retransformação do dinheiro em mercadoria: vender para comprar. A lei do valor se impóe aqui segundo três regras: 1) o valor de uso é a finalidade do movimento; 2) há equivalência na troca; e 3) a apropriação se dá pelo trabalho próprio. Na seção II do Livro I, com a posição do capital, a primeira dessas regras é negada:

O ciclo M-D-M parte do extremo de uma mercadoria e se encerra com o extremo de outra mercadoria, que sai da circulaçáo e entra no consumo. Consumo, satisfação de necessidades, em uma palavra, valor de uso, é, por conseguinte, seu objetivo final. O ciclo D-M-D, ao contrário, parte do extremo do dinheiro e volta finalmente ao mesmo extremo. Seu motivo indutor, sua finalidade determinante é, portanto, o próprio valor de troca. (MARX, 1983, p. 127). 
No entanto, como mostra Fausto (1983), é só na seção VII do Livro I, quando Marx apresenta o processo de reprodução capitalista a partir do encadeamento das voltas do capital, que as outras duas regras são negadas.

\begin{abstract}
Abstraindo toda acumulaçáo, a mera continuidade do processo de produção, ou a reprodução simples, transforma após um período mais ou menos longo necessariamente todo o capital em capital acumulado ou mais valia capitalizada. Se, ao entrar no processo de produçáo, ele tenha sido propriedade pessoal adquirida mediante trabalho de seu aplicador, mais cedo ou mais tarde torna-se valor apropriado sem equivalente ou materialização, seja em forma monetária ou outra, de trabalho alheio não pago. (MARX, 1984a, p.156, grifo nosso). ${ }^{14}$
\end{abstract}

Com base no encadeamento das voltas do capital, portanto, temos um processo de interversão (Umschlagen) da lei do valor. É interversão, porque não se trata de uma inversão trivial, operada externamente, porém, de uma inversão que decorre do funcionamento mesmo da lei, que vem de seu interior, ou seja, o sujeito que opera a inversão da lei é a própria lei. ${ }^{15}$ Com a posição da força de trabalho como mercadoria e, pois, com a posição do capital, a lei do valor se completa, quer dizer, a forma valor atinge a própria substância do valor, a força de trabalho, e inicia, desde esse ponto, o processo de interversão da lei, ainda que o resultado de tal interversão só possa ser plenamente percebido pelo

\footnotetext{
${ }^{14}$ Um exemplo hipotético é suficiente: tomemos um capitalista com $\$ 150$. Num primeiro momento, ele compra força de trabalho pelo seu valor $(\$ 50)$, a utiliza em conjunto com uma massa de capital constante de $\$ 50$ e consome $\$ 50$ para sobreviver. Suponhamos também uma taxa de mais valia de $100 \%$. Ao final do primeiro período, ele obterá um produto de $\$ 150$. No período seguinte, ele novamente compra força de trabalho por $\$ 50$, utiliza mais $\$ 50$ de capital constante, consome $\$ 50$ e obtém $\$ 150$. O mesmo movimento, de reprodução simples, pode repetir-se sucessivamente. Notese que, em determinado momento - no nosso exemplo, a partir do quarto ciclo - ele terá gasto (consumido) todo seu montante inicial e terá mesmo assim os $\$ 50$ destinados a seu consumo, cuja origem é a mais-valia apropriada sem equivalente.

15 Quem chama a atenção para a importância do termo interversão é, mais uma vez, Fausto (1983), para denotá-lo no sentido em que aqui o consideramos. Marx o utiliza, na mesma seçáo VII do Livro I, responsável pela apresentação da negação total das leis da circulação simples pela produção capitalista. A primeira seção do capítulo 22 ("A transformação de mais valia em capital"), que dá conta do processo de reprodução ampliada, denomina-se Kapitalistischer Produktionsprozeß auf erweiterter Stufenleiter. Umschlag der Eigentumsgesetze der Warenproduktion in Gesetze der kapitalistischer Aneignung ("Processo de produção capitalista em escala ampliada. interversão das leis de propriedade da produção de mercadorias em leis de apropriação capitalista" - a tradução brasileira da edição de O Capital aqui usada consigna, para o termo Umschlag, o termo "conversão" - 1984a, p. 163). Na nota 23 do mesmo capítulo, citando o livro Richesse ou Pauvreté, de Cherbuliez, que faz uma afirmação de mesma natureza sobre a propriedade capitalista, Marx observa: [...] wo jedoch dieser dialektische Umschlag nicht richtig entwickelt wird (“[...] onde, entretanto, essa interversão dialética não é desenvolvida de modo correto”).
} 
encadeamento das voltas do capital, isto é, de sua reprodução. ${ }^{16} \mathrm{Na}$ circulação capitalista, todas as trocas particulares seguem a equivalência e é precisamente por causa disso - da plenitude e correção desse movimento - que o capitalista se apropria de trabalho não pago, valor sem equivalente. Vemos então que, “[...] mesmo na reprodução simples todo o capital adiantado, como quer que tenha sido originalmente obtido, transforma-se em capital acumulado ou mais-valia capitalizada” (MARX, 1984a, p. 169). A posição plena da lei do valor, da lei da equivalência, interverte essa lei e póe essencialmente a não equivalência, mantendo, todavia, a equivalência na aparência, vale dizer, nas transaçóes individuais entre capitalista e trabalhador.

Assim, considerado o capital em seu processo de reprodução - não importa se simples ou ampliado -, todas as três regras da lei do valor são negadas: 1) a finalidade da produção não é a troca de mãos de diferentes valores de uso, mas a valorização do valor; ${ }^{17}$ 2) no movimento global, não há equivalência, pois a força de trabalho produz mais-valia; e 3) a apropriação não se dá por intermédio do trabalho próprio, mas pela expropriação de trabalho alheio.

Na seção V do Livro III, por sua vez, Marx nos apresenta o capital portador de juros e à dupla negação operada por ele:

Nunca se deve esquecer que aqui o capital enquanto capital é mercadoria ou que a mercadoria de que se trata é capital. Todas as relaçóes que aqui aparecem seriam, portanto, irracionais do ponto de vista da mercadoria simples, ou também do ponto de vista do capital, à medida que funciona em seu processo de reprodução como capital-mercadoria. (1984c, p. 265).

Por conseguinte, de ambos os "pontos de vista", tanto o da mercadoria (circulação simples) quanto o do capital (reprodução), as determinaçóes postas pelo capital portador de juros aparecem como irracionais, isto é, o capital portador de juros traz consigo determinaçóes que negam ambos os círculos prévios de $O$ Capital. Continuemos a análise deste parágrafo central:

\footnotetext{
${ }^{16}$ Discordamos, todavia, de Fausto, que compreende a posição do capital (seçấo II do Livro I) como a primeira negação do valor e a reproduçáo simples (seção VII do mesmo Livro) como a segunda negação (1983, p.186-192; 1987, p. 16-27). Para nós, esse movimento é um só e põe apenas a primeira negação do valor (tanto no movimento efetivo quanto na apresentação de Marx). A segunda negação, a negação da negação do valor, como veremos, somente se dará com a posiçáo do capital portador de juros, que Marx apresenta nas seçôes IV e V do Livro III.

17 A finalidade é a obtençấo de mais valia "[...] que recebe a forma de uma revenue que provém do capital” (MARX,1984a, p. 153).
} 
Emprestar e tomar emprestado, em vez de vender e comprar, é aqui a diferença que decorre da natureza específica da mercadoria capital. Do mesmo modo que o que se paga aqui é juro, em vez de preço da mercadoria. Se se quiser chamar o juro de preço do capital monetário, então essa é uma forma de expressão totalmente irracional de preço, completamente em contradição com o conceito do preço da mercadoria. O preço se reduz aqui a sua forma puramente abstrata e sem conteúdo, ou seja, ele é determinada soma de dinheiro paga por qualquer coisa que, de uma maneira ou de outra, figura como valor de uso; enquanto, segundo seu conceito, o preço é igual ao valor expresso em dinheiro desse valor de uso. (MARX, 1984c, p. 265-266, grifo nosso).

Eis a forma preço em sua manifestação mais pura: ele nada mais é que "[...] determinada soma de dinheiro paga por qualquer coisa”. Note-se:

Juro como preço de capital é de antemão uma expressão totalmente irracional. Aqui uma mercadoria tem duplo valor: primeiro, um valor e, depois, um preço distinto desse valor, enquanto o preço é a expressão monetária do valor. O capital monetário de início é apenas uma soma de dinheiro [...]. Como pode então uma soma de valor ter um preço além de seu próprio preço, além do preço que está expresso em sua própria forma dinheiro? (MARX, 1984c, p. 266).

A resposta reside no "milagre" mesmo da mercantilização do próprio capital, "milagre" operado pela forma preço e que poderia ser expresso pelo juízo infinito: "a mercadoria é capital". Por um lado, essa mercadoria tem um valor que corresponde ao montante do empréstimo, uma determinada quantia de dinheiro que pode (ou não) ser utilizada como capital, isto é, que pode ter seu valor de uso consumido. Por outro lado, ela tem um preço, o juro, que representa não um valor, mas a valorização mesma do capital: "[...] o capital se manifesta como capital mediante sua valorizaçáo [...]. A maior ou menor valorização do capital portador de juros só é mensurável comparando o montante de juros, a parte que lhe cabe do lucro global, com o valor do capital adiantado" (MARX, 1984c, p. 266).

Temos aqui "[...] um preço que é qualitativamente diverso do valor [e que, portanto,] é uma contradição absurda” (MARX, 1984c, p. 266, grifo nosso $)^{18}$, contradiçáo que deve ser afirmada em seu contrassenso mesmo: deve-

${ }^{18}$ O preço pode operar esse "milagre" exatamente por ser nada mais que "[...] a denominação monetária do trabalho objetivado na mercadoria" (MARX, 1983, p. 92). Observe-se que não se trata aqui, como no caso da honra, consciência etc., de algo que não tem valor, mas que pode ter um preço, desde 
se abandonar a oposição (de um lado..., de outro...) própria ao entendimento, e afirmar a contradição com todas as letras, como faz Marx. O segredo dessa contradição jaz no valor de uso da mercadoria capital:

O pressuposto fundamental é justamente o de que o dinheiro funcione como capital, e, portanto, como capital em si, como capital potencial, possa ser remetido a outra pessoa. Como mercadoria, o capital, entretanto, aparece aqui na medida em que é oferecido no mercado e o valor de uso do dinheiro é realmente alienado como capital. E seu valor de uso, porém, é produzir lucro. O valor do dinheiro ou das mercadorias como capital não é determinado pelo valor que possuem como dinheiro ou como mercadorias, mas pelo quantum de mais valia que produzem para seu possuidor. (MARX, 1984c, p. 266, grifo nosso).

O juro é, pois, esse preço irracional que, diferentemente dos preços de mercado das mercadorias comuns, tem sua grandeza inteiramente determinada pela concorrência, quer dizer, pelas interaçóes entre oferta e procura:

Se procura e oferta se cobrem, o preço de mercado da mercadoria corresponde a seu preço de produçáo [...]. Mas é diferente o que se dá com o juro do capital monetário. A concorrência náo determina aqui os desvios da lei, mas não existe lei alguma de repartição além da ditada pela concorrência. (MARX, 1984c, p. 267). ${ }^{19}$

E, com isso, temos a negação da negação das três regras da lei do valor, mas nem por isso um retorno ao idílico mundo da circulação simples - que o capital portador de juros nega, tanto quanto o mundo da reproduçáo capitalista (segunda negação que frequentemente é esquecida, quando não completamente ignorada) - mas antes, a superação do valor enquanto lei, sua Aufhebung. ${ }^{20}$ Vejamos uma a uma essas regras. Como já indicado, a primeira regra da circulação simples, e que a posição do capital (transformação da

que se coloque sob a forma mercantil, mas de algo que tem um valor e que tem um preço, sendo que o segundo se distingue do primeiro náo só quantitativamente, como pode ocorrer com qualquer mercadoria, mas também qualitativamente. É este o absurdo ao qual Marx se refere.

19 Daí porque se entende "[...] por taxa natural de juros a taxa fixada pela livre concorrência. Não há limites 'naturais' da taxa de juros. Onde a concorrência nâo se limita a determinar os desvios e as flutuaçôes, quando, pois, no equilíbrio de suas forças contrapostas cessa toda determinação em geral, o que se trata de determinar é em si e para si não regulado por lei e arbitrário” (MARX, 1984c, p. 267). Voltaremos a esse ponto na seção seguinte.

${ }^{20}$ Voltaremos ao termo mais à frente, ainda nesta seçấo. 
força de trabalho em mercadoria) nega, é que o valor de uso é a finalidade da circulação (já que no circuito D-M-D' a finalidade é a valorização do valor). No caso da mercadoria capital, porém, seu valor de uso (a produção potencial de mais valor que ela carrega consigo) volta a ser a finalidade do movimento. Contudo, este está longe de ser um valor de uso trivial, o que deixa claro que o movimento da mercadoria capital, ainda que resgate formalmente a regra do valor de uso como finalidade, suspendendo a interversão ao pôr a valorização do valor como o verdadeiro valor de uso, reinstaura a circulaçáo simples de mercadorias, entretanto, de modo a dar-lhe uma nova determinação (a aparência de que mercadorias podem valorizar-se espontaneamente) ${ }^{21}$

A segunda regra que a posição do capital nega é a que afirma a equivalência na troca (já que, quando a mercadoria força de trabalho entra em cena, essa equivalência deixa de existir). Quando a mercadoria em questão é o capital, a "equivalência" é restabelecida. Vimos que o preço se reduz aqui à sua forma pura, mera quantidade de dinheiro (o "ser nada mais que"). Desse modo, qualquer preço se mostra como equivalente, não porque ele não difira do valor, mas exatamente porque não há valor por trás desse preço: qualquer relação será equivalente, isto é, terá um sinal de igual no meio. Para as mercadorias triviais, "[...] a verdadeira dificuldade na determinação geral dos conceitos de procura e oferta é que esta parece levar a uma tautologia" (MARX, 1984c, p. 144); aqui, ao contrário, não apenas somos levados à tautologia, como não há nada além dela. Isso está intimamente relacionado ao fato de que, "[...] no caso do capital portador de juros, tudo aparece como externo" (MARX, 1984c, p. 267). Aqui, mais uma vez, o movimento da mercadoria capital resgata a regra da equivalência, mas se trata de uma equivalência sui generis, que póe o totalmente arbitrário (da definição do juro pela concorrência) como a verdadeira "equivalência".

A terceira regra, que reza que a apropriação se dá pelo trabalho próprio, é negada pela posição do capital, porque, no caso da produção capitalista, a apropriação se dá por meio da expropriação de trabalho alheio. Ora, no caso da mercadoria capital, o trabalho alheio expropriado vai ao encontro de um capital também alheio. Como lembra Marx, o capitalista monetário “[...] faz das poupanças alheias seu capital e do crédito que os capitalistas reprodutivos se dão mutuamente e que lhes dá o público, sua fonte privada de enriquecimento". Assim,

${ }^{21}$ Pense-se nas commodities: café e soja, por exemplo, têm um valor de uso alimentar, mas adquirem outro, ao serem negociados em bolsas de mercadorias e futuros, o de se autovalorizarem. 
[...] a última ilusäo do sistema capitalista, a de que o capital é fruto de trabalho próprio e de poupança própria é com isso liquidada. Náo só o lucro consiste na apropriaçáo de trabalho alheio, mas o capital, com que esse trabalho alheio é posto em movimento e explorado, consiste em propriedade alheia, que o capitalista monetário póe à disposiçấo do capitalista industrial, e pelo qual ele, por sua vez, explora este último. (MARX, 1984c, p. 43, grifo nosso).

Portanto, com o capital portador de juros, a terceira regra é negada, não porque a apropriaçáo "volte" a se dar pelo trabalho próprio, mas porque a incongruência que existia antes entre uma apropriação que se dá pelo trabalho de outrem e uma norma que diz que ela deve se dar pelo trabalho próprio deixa de existir, já que o "próprio" da regra é ele mesmo alheio, externo. A mercadoria capital, ainda que náo redima o movimento de seu pecado de permitir a apropriação pelo trabalho alheio, fornece a essa operação um ponto de partida que possibilita o bloqueio da interversão e póe o alheio como o verdadeiro do próprio.

Isso posto, cabe uma observação sobre o tipo de negação do valor que a posição da mercadoria capital opera. Sabemos que Hegel distingue ao menos dois níveis de negatividade, o segundo deles se desenvolvendo em dois subníveis:

[(1)] a negatividade abstrata (abstrakte Negativität) que às vezes aparece sob o nome de negação simples (einfache Negation) e [2)] a negatividade absoluta (absolute Negation) que às vezes aparece sob o nome de negaçáo da negação: o resultado especulativo de uma negação determinada. No interior da negatividade absoluta podemos determinar ainda outros dois [sub-]níveis de negação representados pelas [a)] interversōes próprias à Umschlagen (ou pelas inversóes próprias à Verkehrung) e pela [b)] superação própria à Aufhebung. (SAFATLE, 2006, p. 132).

Encontramos esses mesmos dois subníveis em Marx: a primeira negação do valor consiste, como bem salienta Fausto (MARX, 1983, 1997), numa interversão da lei do valor. Já a segunda negação apresenta todas as características de uma verdadeira Aufhebung, que resumidamente podemos definir como uma negação essencialmente dialética, uma negação contraditória, porque é uma negação que conserva: “'Conservação' e 'retenção' são dois termos que demonstram como a Aufhebung é, em certo nível, modo de negação que opera supressóes exatamente para poder bloquear as interversóes e para poder pôr na efetividade uma determinação sem invertê-la em seu contrário" (SAFATLE, 2006, p. 135). A mercadoria-capital opera a Aufhebung da lei do 
valor: conserva formalmente as regras da circulação mercantil, impedindo que elas passem no seu contrário, no entanto, o resultado dessa conservação é a negação dessas regras de modo mais efetivo do que o faz a mera posição do capital no movimento clássico de sua circulação (o qual é igualmente negado). Esse, afinal, o "milagre" operado pela mercantilização do capital.

\section{A eXteriorizaçáo do Capital ou o trabalHo do capitalista}

Ao "vender" a mercadoria capital, isto é, ao emprestar uma soma de dinheiro, "[o] capitalista monetário aliena, de fato um valor de uso e, por isso, o que ele entrega é entregue como mercadoria. [...] O lucro é esse valor de uso" (MARX, 1984c, p. 264). O mutuário, por sua vez, consome esse valor de uso, quer dizer, utiliza o montante emprestado para comprar meios de produção e força de trabalho, ou seja, utiliza-o como capital:

[...] ambos, prestamista e mutuário, despendem a mesma soma de dinheiro como capital. Mas só nas mãos deste último ela funciona como capital. [...] Esta [mesma soma de dinheiro] só pode funcionar como capital para ambos mediante repartiçáo de lucro. A parte que cabe ao prestamista chama-se juro. (MARX, 1984c, p. 265).

Inversamente à relação entre trabalho e capital, na qual “[...] de sua diferença qualitativa surge a repartiçáo quantitativa do valor produzido [entre capital circulante/salário e mais-valia]" ou mesmo a repartição da mais valia entre lucro e renda, "[...] no caso do juro, não acontece nada desse gênero. Aí, a distinção qualitativa surge, ao contrário, da repartição puramente quantitativa da mesma soma de mais valia" (MARX, 1984c, p. 273). Repartição que tem como sua causa a dupla figura do capitalista: "[...] na realidade, é somente a separação dos capitalistas em capitalistas monetários e capitalistas industriais que converte parte do lucro em juros e cria, em geral, a categoria do juro; e é apenas a concorrência entre essas duas espécies de capitalistas que cria a taxa de juros" (MARX, 1984c, p. 277). ${ }^{22}$ A pergunta que cabe responder, portanto, é

[...] como essa divisão puramente quantitativa do lucro em lucro líquido e juro se transforma em qualitativa? Em outras palavras, como explicar que também o capitalista que emprega apenas capital próprio e nenhum

\footnotetext{
${ }^{22}$ Não há espaço aqui para analisar a relação entre taxa de lucro e de juros. Vale lembrar, porém, que "[...] a taxa de juros se relaciona com a taxa de lucro da mesma maneira que o preço de mercado com seu valor" (MARX,1984c, p. 273).
} 
emprestado classifique parte de seu lucro bruto na categoria particular de juro e, como tal, a calcule separadamente? E que, portanto, ainda mais, todo capital, emprestado ou não, é distinguido como portador de juros de si mesmo, proporcionando lucro líquido? (MARX, 1984c, p. 278).

A resposta reside no fato de que os capitalistas monetário e funcionante não se confrontam apenas "[...] como pessoas juridicamente diversas, mas como pessoas que desempenham papéis totalmente diversos no processo de reprodução [...]. Um apenas o empresta, o outro o emprega de forma produtiva" $\left(\right.$ MARX, 1984c, p. 279) ${ }^{23}$. Do ponto de vista do capitalista funcionante, do capital dentro do processo de produção,

[...] em contraste com o juro que ele tem de pagar ao prestamista, a partir do lucro bruto, a parte restante, que lhe cabe, do lucro, toma, portanto, necessariamente a forma de lucro industrial [...] [ou] comercial, ou para designá-lo com uma expressão alemã que abrange a ambos, a figura do Unternehmergewinn (ganho empresarial). (MARX, 1984c, p. 279).

\section{Desse modo,}

[...] na forma do juro essa antítese ao trabalho assalariado está apagada; pois o capital portador de juros como tal tem como sua antítese náo o trabalho assalariado, mas o capital funcionante; o capitalista prestamista como tal confronta diretamente o capitalista realmente funcionante no processo de reprodução [...] O capital portador de juros é o capital enquanto propriedade em confronto com o capital enquanto funçáo. Mas, à medida que o capital não funciona, ele não explora os trabalhadores nem entra em antagonismo com o trabalho. (MARX, 1984c, p. 283, grifo do autor).

Vemos assim como o capital, ao se exteriorizar de si mesmo, contraditoriamente internaliza a antítese que o constitui: o conflito social se desloca do trabalho morto frente ao trabalho vivo (relação capital-trabalho), para o confronto entre capital financeiro (capital enquanto propriedade) versus capital produtivo (capital enquanto funçáo): “[...] o ganho empresarial

\footnotetext{
23 "O aplicador do capital, mesmo que trabalhe com capital próprio, se decompóe em duas pessoas, o mero proprietário do capital e o aplicador do capital; seu capital mesmo, com relação às categorias de lucro que proporciona, se decompóe em propriedade do capital, capital fora do processo de produçáo, que proporciona juro em si, e capital dentro do processo de produçáo, que como processante proporciona ganho empresarial" (MARX, 1984c, p. 280-281, grifo do autor).
} 
não constitui antítese ao trabalho assalariado, mas apenas ao juro" (MARX, 1984, p. 283) ${ }^{24}$. Assim,

[...] o capitalista industrial, enquanto diferenciado do proprietário do capital aparece, portanto, não como capitalista funcionante, mas como funcionário também abstraído do capital, como simples portador do processo de trabalho em geral, como trabalhador, e precisamente, como trabalhador assalariado ${ }^{25}[\ldots]$ Ele cria mais valia não porque trabalha como capitalista, mas porque, abstraída sua condição de capitalista, ele também trabalha. (MARX, 1984c, p. 285).

Ao atingir sua forma "mais exteriorizada (äuberlichste) e mais fetichista (fetischartigste), a relação de capital assume a forma “[...] D - D', dinheiro que gera mais dinheiro, valor que se valoriza a si mesmo, sem o processo que medeia os dois extremos" (MARX, 1984c, p. 293). Aqui,

[...] na forma do capital portador de juros, portanto, este fetiche automático está elaborado em sua pureza, valor que valoriza a si mesmo, dinheiro que gera dinheiro, e ele não traz nenhuma marca de seu nascimento. A relação social está consumada como relação de uma coisa, do dinheiro, consigo mesmo. Em vez da transformação real do dinheiro em capital aqui se mostra apenas sua forma sem conteúdo. (MARX, 1984c, p. 294).

A separação plena entre função e propriedade é alcançada pela exteriorização/alienação (Veräuberlichung) ${ }^{26}$ do capital de si mesmo: lado a lado, encontram-se capital funcionante e capital portador de juros. Contraditoriamente, completa-se assim o movimento de internalização iniciado com a concorrência intercapitalista. Ali, "[...] o capital se relaciona consigo mesmo" (MARX, 1984c, p. 37) através da taxa de lucro, “[...]

\footnotetext{
${ }^{24}$ Ao capitalista funcionante "[...] a exploraçấo do trabalho produtivo custa esforço, quer ele mesmo a execute quer ele a faça executar por outros, em seu nome. Em antítese ao juro, seu ganho empresarial se apresenta a ele, portanto, como independente da propriedade de capital, muito mais como resultado de suas funçōes enquanto não-proprietário, enquanto - trabalhador" (MARX, 1984c, p. 284).

25 Eis outro juízo infinito: "[...] o capitalista é trabalhador assalariado". Tudo se passa como se o capitalista funcionante "apenas efetua[sse] outro trabalho que o do trabalhador, de modo que o trabalho de explorar e o trabalho explorado são, ambos, enquanto trabalho, idênticos" (MARX, 1984c, p. 286).

26 Este termo é bem traduzido na edição brasileira por alienaçăo. Todavia, deve ser ressaltado que se trata de alienação no sentido de venda, não no sentido da Entfremdung. No entanto, cremos que a argumentação do capítulo de $O$ Capital aqui utilizado (capítulo XXIV do Livro III) nos permite compreendê-lo como fazendo referência à duplicação do capital (real e monetário), portanto, à sua exteriorização de si mesmo.
} 
portanto, o excedente, para falar com Hegel, se reflete em si mesmo a partir da taxa de lucro" (ibidem). Falemos, pois, com Hegel. A reflexão é momento da essência, essência (mais valia) que, necessariamente aparece (lucro) e que, ao refletir-se sobre si mesma, toma consciência de si mesma e póe-se como fundamento:

Na produção capitalista [...] trata-se, pois, de vender as mercadorias a preços que, pelo menos, proporcionem o lucro médio, isto é, aos preços de produção. Dessa forma, o capital se torna consciente de si mesmo, como uma força social, em que cada capitalista participa proporcionalmente à sua parcela no capital global da sociedade. (MARX, 1984c, p. 149-150, grifo nosso).

Contudo, com a concorrência intercapitalista, temos apenas o primeiro momento desse movimento. A essência deve ser internalizada pelo conceito, o que nos termos de $O$ Capital se traduz pela oposiçáo da concorrência intercapitalista ao capital monetário, isto é, pelo desvanecimento dos limites entre (re)produção e circulação - os dois círculos inferiores - e por sua plena posição como capital monetário:

No mercado monetário confrontam-se apenas prestamistas e mutuários. A mercadoria tem a mesma forma, dinheiro. Todas as formas especiais do capital, conforme seu investimento em esferas particulares da produção ou da circulação, estão aqui apagadas. O capital existe aqui na figura indiferenciada, igual a si mesma, do valor autônomo, do dinheiro. A concorrência entre as esferas particulares cessa aqui; todas elas são confundidas como mutuários de dinheiro, e o capital as confronta todas também na forma em que ele é indiferente à maneira especial de seu emprego. Como aquilo que o capital industrial só aparenta no movimento e na concorrência entre as esferas particulares, como capital comum em si de uma classe, ele surge, aqui de fato, com toda força, na procura e oferta de capital. (MARX, 1984c, p. 275-276, grifo nosso).

O capital portador de juros corresponde, portanto, à plena posição do conceito capital ou, dizendo de outra forma, é apenas com a posição do capital como capital portador de juros que o conceito capital está plenamente desenvolvido. ${ }^{27}$ Ele existe de fato não em sua configuração individual, em que o

${ }^{27}$ Exatamente por isso "[...] o capital portador de juros representa, na imaginação popular, a forma do capital par excellence [...], [pois nele] apresenta-se o caráter auto reprodutor do capital, o valor que se valoriza, a produção que se valoriza, a produção de mais valia como qualidade oculta, em estado puro" (MARX, 1985, p. 118). 
lucro é acidental, tampouco em sua existência como força social, como capital global, clivado pela concorrência, mas antes em sua existência apartada do processo de produção, enquanto figura indiferenciada e abstratamente igual a si mesma, figura que engloba seu outro (o capital industrial) como momento de seu movimento de autovalorizaçáo. Com ao menos uma diferença frente à dialética hegeliana: o capital portador de juros é o fetiche em sua forma mais desenvolvida. "O capital é agora coisa, mas enquanto coisa capital (Das Kapital ist jetzt Ding, aber als Ding Kapital)" (MARX, 1984c, p. 295). ${ }^{28}$ O que ali era autoposição do conceito, aqui é autoposição do fetiche. ${ }^{29}$

\section{O PRINCÍPIO DE CAPITALIZAÇÃO OU A APARÊNCIA CAPITALISTA}

O capital portador de juros opera a Aufhebung do valor, ao internalizar tanto a esfera da circulação quanto a esfera de produção do capital. Ele pode assim fazê-lo porque tem, no corpo do dinheiro, a matéria adequada à pura forma que é. No dinheiro - esse termo médio da circulação (M-D-M) que possibilita a inversão do ciclo e a posição do capital (D-M-D') e que opera a síntese destes dois momentos, ao ser emprestado - se manifestarão, por conseguinte, as consequências da posição do capital como capital portador de juros. Caberá aqui estabelecer a diferença entre dinheiro enquanto dinheiro e dinheiro enquanto capital (moneyed capital) ${ }^{30}$, vale dizer, apontar quais as características do dinheiro nesta nova posição.

A questão central aqui é que "[...] a forma de capital portador de juros faz com que cada rendimento monetário determinado e regular apareça como juro de um capital, quer provenha de um capital ou não" (MARX, 1984c, p. 10). Some-se a isso a possibilidade de transferência da propriedade e teremos o

\footnotetext{
28 A nosso ver, a oração deve ser lida: "O capital é agora coisa, mas, enquanto coisa, capital", com as vírgulas enfatizando a coisidade do capital portador de juros (uma redaçáo mais direta seria simplesmente: "[...] o capital portador de juros é o capital enquanto coisa"). Aliás, não custa lembrar a primeira página de $O$ Capital: "A mercadoria é, à primeira vista, um objeto externo, uma coisa, [...]" (1983, p. 45). Afirmamos, mais uma vez: o círculo se fechou.

29 Será esta a apreensão correta da colocação de Marx no posfácio à segunda edição de $O$ Capital, na qual ele póe sua dialética como a "antítese direta" da dialética hegeliana? Hipótese sedutora, afinal, "[a] mistificação que a dialética sofre nas mãos de Hegel não impede, de modo algum, que ele tenha sido o primeiro a expor as formas gerais de movimento, de maneira ampla e consciente. É necessário invertêla, para descobrir o cerne racional dentro do invólucro místico" (MARX, 1983, p. 20-21).

${ }^{30}$ No movimento de reprodução do capital, o capital monetário é uma das formas do capital, ao lado do capital mercadoria e do capital produtivo. Aqui, ao contrário, ele se confunde com o capital portador de juros.
} 
que Marx denomina capital fictício; capital que, não obstante ser fictício, “[...] tem seu próprio movimento" (MARX, 1984c, p. 10).

A formação do capital fictício chama-se capitalização" ${ }^{31}$ e, com ele, "[...] toda a conexáo com o processo real de valorização do capital se perde assim até o último vestígio, e a concepção de capital como autômato que se valoriza por si mesmo se consolida". Estamos aqui, pois, no puro reino das aparências: "O movimento autônomo do valor destes títulos de propriedade [...] confirma a aparência, como se eles constituíssem capital real ao lado do capital ou do direito ao qual possivelmente dêem título. É que se tornam mercadorias cujo preço tem um movimento e uma fixação peculiares $^{32}$ (MARX, 1985, p. 11, grifo nosso).

No limite, todo valor empregado no processo de produção (capital funcionante) teria no mercado de açóes um duplo, um título que garante a sua propriedade, mas que também pode ser negociado (idem, p.14). Isso implica que seu movimento é determinado não mais pela acumulação real de valor (mediada pela produção e circulação de mercadorias), porém, pela acumulação de "preços" (mediada pela circulação de títulos de toda ordem). É nesse contexto que as crises financeiras assumem seu sentido pleno: assim que estoura uma "[...] dessas bolhas de sabão de capital monetário nominal" (MARX, 1985, p. 13), “[...] a procura por capital de empréstimo é procura de meios de pagamento e nada mais" e, por sua vez, "[...] a procura de meios de pagamentos é mera procura de conversibilidade em dinheiro" (MARX, 1985 , p. 48). Momento, portanto, em que os círculos subordinados (circulação de mercadorias e (re)produçáo capitalista) voltam à tona, e com eles suas determinaçóes: o dinheiro volta a ser procurado como mero meio de pagamentos e não mais como mercadoria-capital; as mercadorias voltam a ser negociadas com base em seu valor de uso original. Em suma, o que é exposto violentamente na crise é a unidade do sistema (1983, p. 100), em que o capital portador de juros é "[...] o todo [que] se apresenta como um círculo de círculos, cada um dos quais é um momento necessário, de modo que o sistema de seus elementos próprios constitui a idéia completa que igualmente

\footnotetext{
31 De maneira geral, o capital fictício surge sempre que "[...] na concepção do banqueiro, dívidas podem aparecer como mercadorias” (MARX, 1985, p. 10).

32 Os preços desses títulos (capital fictício) são determinados: 1) pelo montante dos rendimentos; 2) pela segurança dos rendimentos; e 3) pela especulação, além de variarem - supostos estes três constantes - na "[...] razão inversa da taxa de juros" (1985, p. 12), o que constitui a forma de manifestação dessa relação antitética entre os dois tipos de capitalistas.
} 
aparece em cada elemento singular”33 (HEGEL, 1995, \$15, grifo nosso). Terceiro círculo onde a imediaticidade é restaurada através da posição de uma aparência eminentemente capitalista, onde mercadorias seriam capazes de valorizar-se espontaneamente. ${ }^{34}$

Todavia, a crise acaba por expor também a diferença fundamental entre os sistemas idealistas (especialmente o de Hegel) e o de Marx: a liberdade que a crise abala e que sustenta $O$ Capital é a da mercadoria - liberdade que se manifesta numa crescente (mas, como a crise demonstra, nunca absoluta) autonomizaçáo do produto do trabalho perante seu produtor (PAULANI, 2009) - e não a do pensamento. Eis o único enfoque em que falar de dialética materialista faz sentido. ${ }^{35}$

\footnotetext{
${ }^{33}$ Uma questão que, por motivos de espaço, não pôde ser incluída no presente artigo é a relação entre capital portador de juros e capital usurário, a qual nos levaria diretamente à questão da relação entre sistema e história, lógica e contingência.

${ }^{34}$ Não estará aí a conexão do sublime e do ínfimo, operada por Keynes? Recuperemos a discussão sobre taxa de juros que ele faz, no famoso capítulo 17 de sua Teoria Geral: "A taxa monetária de juros - queremos chamar a atenção do leitor - outra coisa não é que a percentagem de excedente de uma soma de dinheiro contratada para a entrega futura, por exemplo, a um ano de prazo, sobre o que podemos chamar o preço 'spot' ou à vista da dita soma contratada para a entrega futura. Parece, portanto, que para cada categoria de bens de capital deveria existir uma taxa análoga à do juro sobre o dinheiro. Pois há uma quantidade definida de (por exemplo) trigo para ser entregue dentro de um ano, que tem hoje o mesmo valor de troca de 100 'quartos' de trigo para a entrega imediata. Se a primeira quantidade é de 105 'quartos', podemos dizer que a taxa de juros do trigo é de $5 \%$ ao ano, e se é 95 'quartos', dizemos que é menos de $5 \%$ ao ano. Assim para cada bem durável temos uma taxa de juros calculada em termos do próprio bem - uma taxa de juros do trigo, uma taxa de juros do cobre, uma taxa de juros da habitaçáo, uma taxa de juros de uma usina siderúrgica" (KEYNES, 1983, p. 157). A singularidade do pensamento de Keynes consistiria no fato de ele partir da imediaticidade reconstruída: a mercadoria é tanto ponto de partida como ponto de chegada, porém, ao final do trajeto ela adquiriu um valor de uso próprio à mercadoria capital (a sua taxa natural de juros). Uma posição que é exclusiva da mercadoria sagrada e absoluta (dinheiro) adere, com isso, às mercadorias banais. Este parece ser também o sentido da passagem em que Marx conceitua o que poderíamos, anacronicamente, denominar capital humano: "A loucura da concepção capitalista atinge aí seu ápice: em vez de explicar a valorização do capital pela exploração da força de trabalho, é, ao contrário, a produtividade da força de trabalho que é explicada pela circunstância de que a própria força de trabalho é esta coisa mística, capital portador de juros" (1985, p. 11). A loucura que Marx apontava para a força de trabalho se estende para todo o mundo das mercadorias.
}

35 "Por meio da passagem para o primado do objeto, a dialética se torna materialista" (ADORNO, 2009, p. 165). 
MÜLLER, Leonardo André Paes; PAULANI, Leda Maria. Interest-bearing capital in Capital or the system of Marx. Trans/Form/Açâo, Marília, v. 35, n. 2, p. 69-70, Maio/Ago., 2012.

\begin{abstract}
The present article seeks to establish the place and function of monetary capital (Zinnsträgende Kapital) in Marx's Capital, with the aim of illuminating the systematic structure of this work. In this way, Marx's great work shows itself to be very close to German Idealism (mainly Fichte and Hegel), where the question of (philosophical) systematicity was felt most vividly.
\end{abstract}

KEYWORDS: System Circle. Negation. Value. Capital. Interest.

\title{
REFERÊNCIAS
}

ADORNO, Theodor W. Dialética negativa. Rio de Janeiro: Jorge Zahar, 2009.

ARANTES, Paulo. Hegel-A Ordem do Tempo. São Paulo: Hucitec, 2000.

FAUSTO, Ruy. Dialética Marxista, Dialética Hegeliana: a Produção Capitalista como Circulação Simples. São Paulo: Brasiliense, 1997.

- Marx: Lógica e Política - Investigaçóes para a Reconstituição do Sentido da Dialética, Tomo I. São Paulo: Brasiliense, 1983.

- Marx: Lógica e Política - Investigações para a Reconstituição do Sentido da Dialética, Tomo II. São Paulo: Brasiliense, 1987.

- Marx: Lógica e Política - Investigações para a Reconstituição do Sentido da Dialética, Tomo III. São Paulo: Editora 34, 2002.

FICHTE, J.G. Sobre o Conceito da Doutrina da Ciência ou da Assim Chamada Filosofia. Fichte \& Schelling. São Paulo: Abril Cultural, 1794/1973. p.15-35 (Coleção "Os Pensadores").

HEGEL, G.W.F. Enciclopédia das Ciências Filosóficas em Compêndio - I: A Ciência da Lógica. São Paulo: Loyola, 1995. . Fenomenologia do Espírito. Petrópolis: Vozes, 2002.

—. Phaenomenologie des Geist. Hamburgo: Felix Meiner, 1952.

Wissenschaft der Logik I. Frankfurt am Main: Suhrkamp, 1986a.

. Wissenschaft der Logik II. Frankfurt am Main: Suhrkamp, 1986b.

HÖSLE, Vittorio. O Sistema de Hegel. São Paulo: Loyola. 2007. 
KEYNES, John Maynard. Teoria Geral do Emprego, dos Juros e da Moeda. São Paulo: Abril Cultural, 1984 (Coleção “Os Economistas”).

LEBRUN, Gerard. Kant et la Fin de la Métaphysique. Paris: Armand Colin, 1971.

MARX, Karl. O Capital, Livro I - Tomo 1. São Paulo: Abril Cultural, 1983 (Coleção “Os Economistas").

Economistas").

O Capital, Livro I - Tomo 2. São Paulo: Abril Cultural, 1984a (Coleção “Os

—. O Capital, Livro II. São Paulo: Abril Cultural, 1984b (Coleção “Os Economistas”).

—. O Capital, Livro III - Tomo 1. São Paulo, Abril Cultural, 1984c (Coleção "Os Economistas").

. O Capital, Livro III - Tomo 2. São Paulo, Abril Cultural, 1985 (Coleção "Os Economistas").

. Para a Crítica da Economia Política. Marx. São Paulo: Abril Cultural, 1974. p.107263 (Coleção “Os Economistas”).

MARX, Karl; ENGELS, Friedrich. Werke. Berlim: Dietz, 1964.

PAULANI, Leda. A Autonomização das Formas Verdadeiramente Sociais na Teoria de Marx: comentários sobre o dinheiro no capitalismo contemporâneo. In: ENCONTRO NACIONAL DE ECONOMIA, XXXVII. Anais eletrônicos... ANPEC, Foz do Iguaçu, 2009.

SAFATLE, Vladimir. Linguagem e Negação: sobre as relaçôes entre ontologia e pragmática em Hegel. Dois Pontos. São Carlos-Curitiba, v. 3, nº 1, p.109-146, 2006.

Recebido em: 04.02.2011

Aceito em: 30.10.2011 